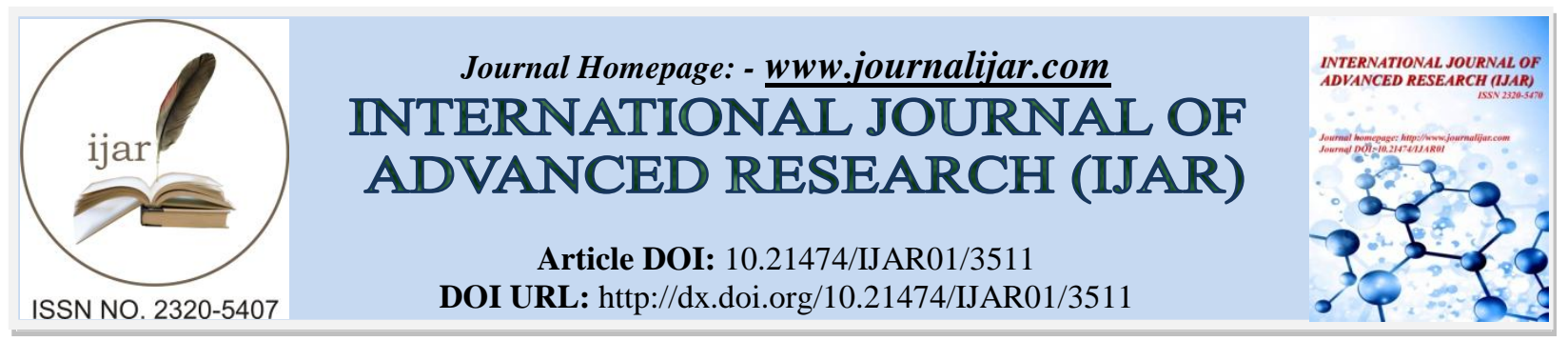

RESEARCH ARTICLE

\title{
EVALUATION OF STRAWBERRY CULTIVARS FOR GROWTH AND YIELD CHARACTERISTICS IN SUB TROPICAL REGION OF PUNJAB.
}

Amarjeet Kaur, Rajandeep Singh and Harmeet Singh.

Department of Agriculture (Horticulture), Khalsa College, Amritsar -143001.

\section{Manuscript Info}

Manuscript History

Received: 08 January 2017

Final Accepted: 05 February 2017

Published: March 2017

Key words:-

Strawberry, Chandler, Selva, yield,

Tioga, Fern, RBD, Blackmore.

\section{Abstract}

A research trial was carried out in the experimental field of Department of Horticulture, Khalsa College, Amritsar during the year 2015-2016 to evaluate some strawberry cultivars in sub tropical region of Punjab. The runners of five strawberry cultivars i.e.. Chandler, Tioga, Fern, Selva and Blackmore were planted at $30 \times 40 \mathrm{~cm}$ apart on the raised beds at three planting times of mid October, end October and mid of November respectively. The design of experiment was Randomised block design (RBD) with factorial arrangement. The results of the study indicated that out of the cultivars tried, the strawberry cv. Chandler proved to be the best in producing maximum number of shoots, leaves, runners and flowers along with yield parameters while strawberry cv. Selva was the least among all these parameters. Out of the times of planting, middle of October proved to be the best in all the parameters.

Copy Right, IJAR, 2017,. All rights reserved.

\section{Introduction:-}

The modern cultivated strawberry (Fragariax ananassaDuch.) is a hybrid of two largely dioecious, octoploid species, Fragaria chelonesis Duch and Fragaria virginiana Duch. Basically, it is herbaceous perennial and short day plant grows predominantly in the temperate climate. Strawberry is known for its pleasant aroma. It is amongst the few crops, which gives quick and very high returns per unit area on the capital investment, as the crop is ready for harvesting within six months of planting(Bakshi et al, 2014). It is a crop cherished by the growers of sub-tropical and temperate regions of the world due to its low cost of growing and high returns per unit area .It is widely, adapted in geographically diverse areas in world (Biswas et al. 2009). It can also be cultivated successfully under subtropical climate of Punjab (Dhillon, 2005).It is cherished in gardens and commercial fields with glamorous red, delicious with a unique shape, highly perishable fruit with a pleasant flavor. It is refreshing, nutritious soft fruit having a distinct tantalizing aroma (Sharma and Yamdagni , 2000). It is highly nutritious having a rich source of vitamins $\mathrm{A}, \mathrm{B}, \mathrm{C}$ and niacin, minerals like phosphorus, potassium, calcium and iron (Karkara and Dwivedi, 2002). It is utilized for the production of purees, juice concentrate, jams, preserves and rose red wine. Medicinally, strawberries have been known to kill certain viruses like polio ,herpes and these may block the formation of nitosamines, which can cause cancer, furthermore these contain relatively high quantities of ellagic acid, which has a wide range of biological activity only recently discovered (Rieger, 2006).The wide diversity of strawberry plant gives an idea of its potential for selection work. Choice of cultivars is of paramount importance for successful strawberry cultivation (Asrey and Singh, 2004; Ahsan et al. 2014).Selection of new stable strawberry cultivars for field condition can ensure better yield and quality. Considering above facts the present study work was undertaken with a view to determine the performance of different strawberry cultivars. 


\section{Materials and Methods:-}

The present experiment was conducted in the nursery of Horticulture Department, Khalsa College, Amritsar during 2014-15. The runners of strawberry cv. Chandler, Tioga, fern, selva and Blackmore were planted. A unit of 10 runners comprising a treatment was planted in each plot, $30 \mathrm{~cm}$ apart on the raised ridges at three times of planting i.e. mid of October, end of October and mid of November taking care that the crown of the runners lies just at the surface of soil. The experiment was laid out according to randomized block design with factorial arrangement with three replications. The observations were recorded on vegetative, floral characteristics and yield parameters. The pooled data of both the years were analysed statistically.

\section{Results and Discussion:-}

Maximum shoot number plant ${ }^{-1}$ (7.94 during first and 8.34 during second season) was counted in strawberry planted on end of Oct $\left(\mathrm{T}_{2}\right)$ during both the cropping seasons, it was followed by mid of Nov $\left(\mathrm{T}_{3}\right)$ and mid of Oct $\left(\mathrm{T}_{1}\right)$ in the first season which recorded 7.51 and 5.67 shoot number respectively and mid Oct $\left(\mathrm{T}_{1}\right)$ and $\left(\mathrm{T}_{3}\right)$ times in the second cropping season with 7.87 and 5.56 shoots respectively. The differences were found to be statistically significant. Maximum shoot number plant ${ }^{-1}$ (8.05) was observed in cv. Chandler during first cropping season, it was followed by cvs. Tioga (7.95) and Blackmore (7.52) while the cvs. Fern and Selva recorded 5.95 and 5.73 shoot number respectively. In the second cropping season of study maximum shoot number plant ${ }^{-1}(10.35$ each) was counted in cvs. Chandler. It was followed by cvs Tioga, Blackmore and Fern with 8.10, 7.77 and 6.58 shoot number plant $^{-1}$ which was found to be at par with the former two cultivars and minimum shoot number per plant to the tune of 6.01 was recorded in cv. Selva. The differences were found to be statistically significant. The interaction between the time of planting and type of cultivars were also found to be statistically significant during both the years of study. In the first year maximum shoot number plant ${ }^{1}$ (9.11) was counted in cv. Blackmore planted during end of Oct $\left(\mathrm{T}_{2}\right)$ in the cropping season it was $10.00 \mathrm{in} \mathrm{cv}$. Chandler planted on mid of Oct $\left(\mathrm{T}_{1}\right)$ and minimum (5.09) in cv. Fern planted on mid Nov $\left(\mathrm{T}_{3}\right)$. The varying shoot number may be due to the temperature variation, changing weather conditions which affects growth of plants. The variation in shoot number in different varieties may be due to the particular varietal character and their growth habits.

The time of planting and type of cultivars exerted significant effect with respect to the number of leaves per plant. Maximum leaf number plant ${ }^{1}$ (19.71 during first and 21.02 during second cropping season) was recorded in planting time of mid Oct $\left(\mathrm{T}_{1}\right)$,it was followed by end Oct $\left(\mathrm{T}_{2}\right)$ and mid Nov $\left(\mathrm{T}_{3}\right)$ planting time which recorded 19.46 and 18.69 leaf number during first season, 19.52 and 18.63 leaf number per plant respectively during the second cropping season of study. In the first year the differences during all the three times were found to be statistically at par with each other while in the second year of study the time $\mathrm{T}_{3}$ showed statistically non significant differences. Maximum number of leaves (23.78 in first and 24.15 in second cropping season) were counted in cv. Chandler followed by cv Tioga (23.62 in first season and 23.84 in second cropping season) and cv. Blackmore (23.01 in first and 23.38 in second cropping season), while minimum leaf number (10.11 in first and 10.45 in second cropping season) was recorded in cv. Fern during both the cropping seasons. The differences were found to be statistically significant. The interaction between cultivars and the planting time were found to be statistically significant with regard to the leaf number plant ${ }^{-1}$ during both the cropping season of investigation. Maximum leaf number plant ${ }^{-1}$ (24.75 during first and 25.92 during second cropping season) was recorded in cv. Chandler planted on mid Oct ( $\mathrm{T}_{1}$ ) as against minimum (9.00 during first and 8.20 during second cropping season) in cv. Fern planted on end Oct ( $\mathrm{T}_{2}$ ) during both the cropping seasons.

The maximum leaf area $94.17 \mathrm{~cm}^{2}$ during first cropping season was measured in runners planted on end Oct $\mathrm{T}_{2}$ but during second cropping season it was $93.51 \mathrm{~cm}^{2}$ in $\mathrm{T}_{1}$. Leaf area produced by $\mathrm{T}_{2}$ planting time remained at par with its following time of planting during both the cropping seasons and the differences were found to be statistically significant. Different cultivars also found effective in altering leaf area in both the cropping seasons of study, cv. Blackmore produced maximum leaf area $\left(110.97 \mathrm{~cm}^{2}\right.$ during first and $110.35 \mathrm{~cm}^{2}$ during second cropping season), it was followed by cv. Chandler with $107.86 \mathrm{~cm}^{2}$ and $107.38 \mathrm{~cm}^{2}$ leaf area in the first and second cropping seasons. Minimum leaf area was obtained in cv. Selva during both the years of study. The differences were found to be statistically significant during both the cropping seasons of study. The interactions between planting time and strawberry cultivars exhibited significant effects in both the years of investigation where the maximum leaf area $112.25 \mathrm{~cm}^{2}$ and $110.38 \mathrm{~cm}^{2}$ were produced by $\mathrm{cv}$. Blackmore in end Oct $\left(\mathrm{T}_{2}\right)$ planting time. Variation in leaf area among different strawberry cultivars could be attributed to the fact that different progenies may have reacted differently to photoperiod, light, temperature and status of media (Darrow, 1966 and Tanaka and 
Mizuta,1974).Hence, it seems that a negative correlation between these two character variable between these two variables coexists. According to Dhillon (2005) plant condition or environment or both affect these two variables differentially or independently.

In the first cropping season runners of $\mathrm{T}_{1}$ planting took 177.0 days for runner formation which is significantly higher than the $\mathrm{T}_{2}$ and $\mathrm{T}_{3}$ plantings which took 164.0 and 155.0 days for runner formation. During the second cropping season significantly more (176.0) days were taken by runners of $T_{1}$ planting than $T_{2}$ and $T_{3}$ plantings which registered 164.0 and 156.0 days for runner formation. During both the cropping seasons cv. Chandler took minimum days (154.0 days during first and 152.0 days during second cropping season) for runner formation followed in line by cvs. Blackmore, Fern, Selva and Tioga which registered 162.0, 165.67, 170.0 and 175.0 days during first cropping season and 159.0, 164.4, 172.0 and 180.0 days for runner formation respectively. The interaction between time and cvs. were found to be non- significant statistically. The vast differences in the time of runner formation, runners plant ${ }^{-1}$ in the various cultivars may be ascribed either a varietal character or genetic make up of the plants or both which affect the plants to react differently under the same agro-climatic conditions. The temperature of the site also affected the runner formation. These results are in line with the findings of Dhillon 2005 respectively.

Time of planting influenced number of runners emerged per plant significantly. Maximum number of runners (4.92)

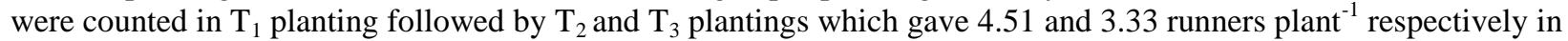
the first cropping season and in the consecutive season, $\mathrm{T}_{1}$ was also able to produce maximum (5.36) runners followed by $\mathrm{T}_{2}$ and $\mathrm{T}_{3}$ timings with 4.72 and 3.52 number of runners plant ${ }^{-1}$. The difference during both the cropping seasons were found to be statistically significant.All the cultivars showed a great variation with respect to number of runners plant ${ }^{-1}$ among each other. Maximum number of runners plant ${ }^{-1}$ (6.25) were obtained in cv. Chandler, it was closely followed by the cvs. Blackmore and Fern during the first cropping season which gave 6.03 and 4.26 number of runners plant ${ }^{-1}$ while cv. Tioga registered minimum (1.30) runners plant ${ }^{-1}$. During the second season cv. Chandler produced 6.80 runners plant $^{-1}$ followed by cvs. Blackmore, Fern and Selva with 6.22, 4.42 and 3.73 runners plant ${ }^{-1}$ while cv. Tioga registered minimum runners. Similar results have been reported by Athwal (1976), Singh (1979) and Singh (1982) under Punjab conditions which further confirms the results of the present study.The interaction of planting time and different cultivars were found to be statistically non- significant .

The data with regard to the number of days taken for flower initiation depicted that during first cropping season minimum average days taken for flower initiation were in the planting of $\mathrm{T}_{3}$ (121.54 days) while the planting of $\mathrm{T}_{2}$ and $\mathrm{T}_{1}$ times taken little more time i.e. 122.14 and 122.61 days for flower initiation, but the differences were found to be statistically non-significant. During the second cropping seasons, time of planting $\mathrm{T}_{3}$ also recorded minimum 121.73 days taken for flower initiation followed by $\mathrm{T}_{2}$ and $\mathrm{T}_{3}$ planting times which took 122.55 and 122.83 days. During both cropping season the difference were found to be statistically significant.It is obvious from the data that different cvs. showed appreciable differences in respect of number of days taken for flower initiation and the differences were found to be statistically significant during both the cropping season of study. In the first cropping season cv. Fern took minimum (120.53) number of days for flower initiation followed in ascending order by cvs. Blackmore, Tioga, Chandler and Selva with 121.34, 121.55, 121.79 and 125.31 days respectively. In the second cropping season again cv. Fern took minimum (120.68) days for flower initiation followed in ascending order in cvs. Tioga, Chandler, Blackmore and Selva with 121.41, 122.02, 122.15 and 125.61 days respectively. It was noted that during both the cropping seasons cv. Selva took maximum number of days flower initiation. The interaction between time of planting and cultivars was found to be non-significant statistically during both the cropping seasons.

The saplings planted during mid Oct $\left(\mathrm{T}_{1}\right)$ time took maximum days for flowering (118.88 days during first and 115.81 days during second cropping season) followed by end Oct times of planting with 97.16 days during first, 98.51 days during second cropping season while the time of planting $\mathrm{T}_{3}$ registered 82.19 days during first, 87.22 days during second cropping season. The differences were found to be statistically significant during both the cropping seasons. In the first cropping season cv. Selva remained in flowering for 105.75 days followed by cv. Fern and Blackmore with 103.29 and 100.54 days of flower duration respectively and these three remained at par with each other while the cv. Tioga and Chandler recorded minimum 93.93 and 93.55 days duration of flowering. In the second year of study cv. Selva remained successive with having 103.81 days of flower duration and it was followed by cv. Fern and Blackmore with 102.51 and 102.41 days duration in flowering and likewise the former season of study these were also remained at par with each other and minimum duration of flowering was noted in cvs. Tioga and Chandler with 100.26 and 93.57 days respectively. The results of the present study are collaborated by the findings of Dhiman (2003). However, Dhaliwal and Singh (1983) while working on strawberry in Ludhiana 
conditions, Beniwal et al (1989) and Kidmos et al. (1996) in Denmark conditions recorded similar type of observations which confirms the findings of present study. The interaction between planting time and cultivars were found to be non- significant statistically during both the years of study.

The maximum number of flowers were registered during the mid Oct $\left(\mathrm{T}_{1}\right)$ planting time which was followed by end Oct $\left(T_{2}\right)$ and mid Nov $\left(T_{3}\right)$ during both the years. During the first cropping seasons planting time $T_{1}, T_{2}$ and $T_{3}$ recorded 13.37, 13.27 and 13.15 number of flowers plant ${ }^{-1}$ respectively and during the second cropping season the times of planting $T_{1}, T_{2}$ and $T_{3}$ registered $13.41,13.25$ and 13.22 flower plant ${ }^{-1}$ respectively, but the differences only in the first cropping season were found to be statistically non-significant.The kind of cultivar showed statistically significant differences with regard to number of flowers plant ${ }^{-1}$ during both the cropping seasons. The cvs. Chandler, Blackmore, Tioga, Fern and Selva recorded 15.22, 15.14, 13.68, 11.18 and 11.08 number of flowers plant ${ }^{-1}$ during the first and during the second cropping season, these were 15.35, 15.05, 13.73, 11.16 and 11.17 respectively, same pattern in the orderliness was noted with regard to the variation in the cultivars during both the cropping seasons. The interactions between time of planting and type of cultivars were found to be non-significant statistically during both the cropping seasons.

During both the seasons $\mathrm{T}_{1}$ time of planting registered maximum number of fruit set plant ${ }^{-1}$ (11.21 during first and 11.18 during second cropping season) followed by $\mathrm{T}_{2}$ (10.79 during first and 10.83) during second cropping season and $\mathrm{T}_{3}$ (10.53 during first and 10.56 during second cropping season). Significant differences were observed on number of fruit set plant ${ }^{-1}$ due to the type of cultivars. During the cropping season number of fruit set plant ${ }^{-1}$ were maximum in cv. Chandler followed by cvs. Black more and Tioga with 13.41, 12.43 and 10.31 number of fruit set plant $^{-1}$ while the minimum (8.73) number was recorded in cv. Selva, Same pattern of number of fruit set plant ${ }^{-1}$ was observed during the second cropping season where the cvs. Chandler, Blackmore, Tioga, Fern and Selva registered $13.47,12.40,10.35,9.31$ and 8.74 of fruit set plant ${ }^{-1}$. It was noted that the fruit set per cent was reduced with the planting time as the early planted saplings received the favourable climatic conditions but the saplings planted in the mid Nov faced the low chilling temperature rising temperature at the fruit set time which resulted in the complete necrosis of the developed fruit or the flower. Per cent fruit set of strawberry depends upon the agro-climatic field conditions of the place of there cultivation. Different research workers reported variability in the per cent fruit set of various varieties depending upon agro-climatic conditions of the area of cultivation. Singh (1982) reported maximum per cent fruit set of Pusa Early Dwarf followed by cv. Tioga under Ludhiana agro climatic conditions of Punjab. The variability in the per cent fruit set under Amritsar's prevailing agro-climatic conditions may be due to the effect of temperature and humidity of the area.The interaction between time of planting and type of cultivars was found to be statistically non significant.

The early plantation resulted in maximum yield then it showed descending trend with the late plantations during both the cropping seasons. In the first cropping season planting times $T_{1}, T_{2}$ and $T_{3}$ registered 115.71, 104.32 and $83.34 \mathrm{~g}$ yield plant ${ }^{-1}$ respectively and in the second cropping season it was $117.98,103.35$ and $81.05 \mathrm{~g} \mathrm{plant}^{-1}$ respectively and differences were found to be significant statistically during both the cropping seasons.It is also evident from the data that statistically significant differences were observed in the yield plant ${ }^{-1}$ of different cultivar. The maximum yield plant ${ }^{-1}$ to the tune of $137.15 \mathrm{~g}$ on average basis was obtained in $\mathrm{cv}$. Chandler, $\mathrm{cv}$. Blackmore with a yield of $116.47 \mathrm{~g} \mathrm{plant}^{-1}$ stood runner up, followed in line were cvs. Tioga, Fern and Selva with 109.18, 86.91 and $55.91 \mathrm{~g} \mathrm{plant}^{-1}$ yield respectively while during the first cropping season. During the second cropping season cv. Chandler registered $134.94 \mathrm{~g}$ plant $^{-1}$ yield followed by cvs. Blackmore, Tioga, Fern and Selva with 117.00, 106.25, 85.65 and 60.22 $\mathrm{g} \mathrm{plant}^{-1}$ fruit yield. Sharma and Yamdagni (2000) also reported cv. Chandler as high yielding cultivar amongst other cultivars and mentioned variability in the yield and marketable yield of strawberry fruits of different cultivars. The yield plant ${ }^{-1}$ also decreased with the planting time. Similar observations on yield plant ${ }^{-1}$ have been reported in different cvs. of strawberry by Singh (1982) and Sharma and Badiyala (1980). These results are in accordance with the findings of several research workers (Bedarad et al.,1971; Lal and Seth, 1980; Hancock et al., 1983. They found a strong correlation with fruit number per plant and weight with total fruit yield but in contrast Dhaliwal and Singh (1983) reported that higher yield of strawberry cultivars was due to number of fruits per plant which may be smaller and lighter in size. The interaction between cvs. and the planting time were found to be non significant during both the seasons of study.

The yield attributes of marketable yield were influenced significantly with the advancement in time of plantation during both the cropping seasons. The time of planting $\mathrm{T}_{1}, \mathrm{~T}_{2}$ and $\mathrm{T}_{3}$ yielded 114.00, 103.18 and $81.26 \mathrm{~g} \mathrm{plant}^{-1}$ marketable yield respectively in the first cropping season and $117.33,102.69$ and $80.72 \mathrm{~g} \mathrm{plant}^{-1}$ marketable yield 
during the second cropping season and differences were found to be statistically significant during both the seasons of cropping.The type of cultivars also showed their effect on the marketable yield of strawberry fruits during both the cropping seasons. The cv. Chandler yielded maximum marketable fruits to the tune of $135.71 \mathrm{~g}$ plant $^{-1}$ and 133.31g plant ${ }^{-1}$ during first and second cropping seasons. The cvs. Blackmore, Tioga, Fern and Selva followed the cv. Chandler by registering $114.65,106.26,83.46$ and $57.31 \mathrm{~g} \mathrm{plant}^{-1}$ (minimum) marketable yield respectively during the first cropping season and in the second season these were $116.47,106.68,85.59$ and $59.19 \mathrm{~g} \mathrm{plant}^{-1}$ (minimum) marketable yield respectively and the differences were found to be statistically significant . The interaction between the time of planting and different type of cultivars were found to be statistically non-significant during both the cropping seasons.

Table 1: Effect of planting time and cultivars on shoot number plant ${ }^{-1}$ of strawberry.

\begin{tabular}{|c|c|c|c|c|c|c|c|c|}
\hline Cultivar & $\begin{array}{c}2014-15 \\
\mathrm{~T}_{1}\end{array}$ & $\mathrm{~T}_{2}$ & $\mathrm{~T}_{3}$ & Mean & $\begin{array}{c}2015-16 \\
\mathrm{~T}_{1}\end{array}$ & $\mathrm{~T}_{2}$ & $\mathrm{~T}_{3}$ & Mean \\
\hline Chandler & 7.03 & 8.10 & 9.02 & 8.05 & 10.00 & 12.50 & 8.55 & 10.35 \\
\hline Tioga & 6.75 & 9.00 & 8.12 & 7.95 & 8.03 & 8.07 & 8.21 & 8.10 \\
\hline Fern & 5.48 & 6.33 & 6.05 & 5.95 & 7.22 & 7.44 & 5.09 & 6.58 \\
\hline Selva & 4.00 & 7.19 & 6.00 & 5.73 & 5.11 & 5.59 & 7.34 & 6.01 \\
\hline Blackmore & 5.12 & 9.11 & 8.34 & 7.52 & 9.00 & 8.11 & 6.22 & 7.77 \\
\hline Mean & 5.67 & 7.94 & 7.51 & & 7.87 & 8.34 & 5.56 & \\
\hline \multicolumn{9}{|c|}{$\operatorname{LSD}(\mathrm{P}=0.05)$} \\
\hline \multicolumn{3}{|c|}{ Time } & 1.05 & & & & & 1.92 \\
\hline \multicolumn{3}{|l|}{ Cvs. } & 1.35 & & & & & 1.48 \\
\hline \multicolumn{3}{|c|}{ Time x Cvs. } & 1.12 & & & & & 0.23 \\
\hline
\end{tabular}

Table 2: Effect of planting time and cultivars on leaf number plant ${ }^{-1}$ of strawberry.

\begin{tabular}{|c|c|c|c|c|c|c|c|c|}
\hline & $20014-15$ & & & & $2015-1$ & & & \\
\hline Cultivar & $\mathrm{T}_{1}$ & $\mathrm{~T}_{2}$ & $\mathrm{~T}_{3}$ & Mean & $T_{1}$ & $\mathrm{~T}_{2}$ & $\mathrm{~T}_{3}$ & Mean \\
\hline Chandler & 24.75 & 24.10 & 22.50 & 23.78 & 25.92 & 23.47 & 23.07 & 24.15 \\
\hline Tioga & 24.28 & 24.25 & 22.34 & 23.62 & 25.35 & $25 . .17$ & 21.01 & $23 . .84$ \\
\hline Fern & 10.36 & 9.00 & 10.96 & 10.11 & 12.34 & 8.20 & 10.82 & 10.45 \\
\hline Selva & 15.10 & 17.13 & 19.35 & 17.25 & 16.29 & 17.08 & 17.02 & 16.80 \\
\hline Blackmore & 24.06 & 24.10 & 20.88 & 23.01 & 25.20 & 23.70 & 21.25 & 23.38 \\
\hline Mean & 19.71 & 19.46 & 18.69 & & 21.02 & 19.52 & 18.63 & \\
\hline
\end{tabular}

$\operatorname{LSD}(\mathrm{P}=0.05)$

$\begin{array}{lll}\text { Time } & 1.72 & 1.48 \\ \text { Cvs. } & 1.85 & 1.91 \\ \text { Time x Cvs. } & 0.56 & 0.12\end{array}$

Table 3: Effect of planting time and cultivars on leaf area $(\mathrm{cm})^{2}$ of strawberry.

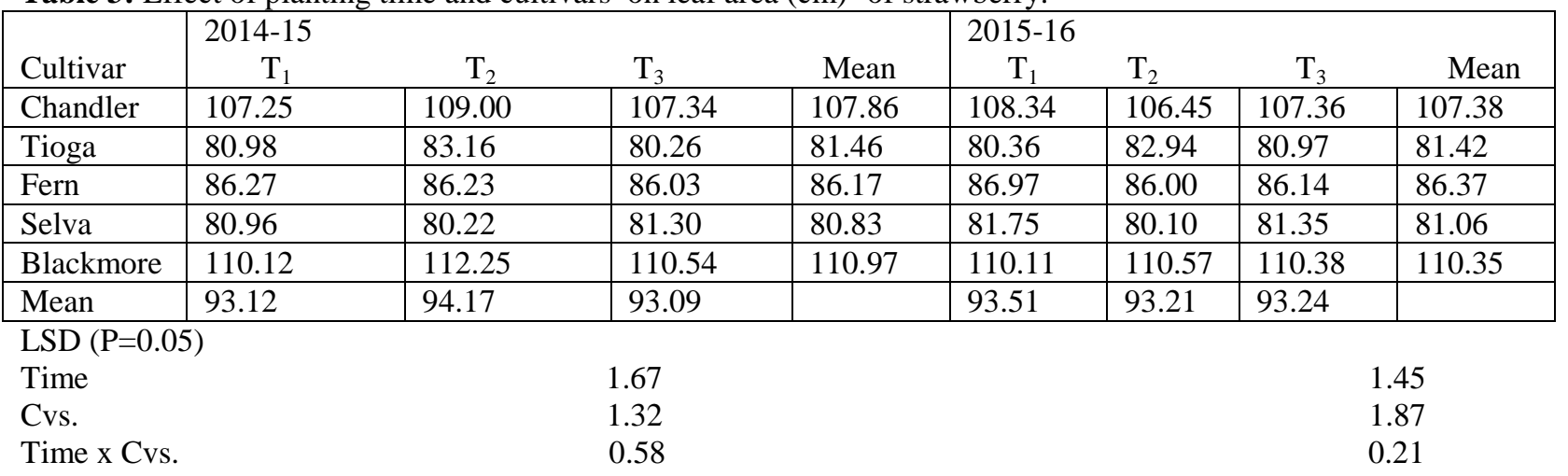


Table 4: Effect of planting time and cultivars on time taken for runner formation (days) of strawberry

\begin{tabular}{|c|c|c|c|c|c|c|c|c|}
\hline Cultivar & $\begin{array}{c}2014-15 \\
\mathrm{~T}_{1}\end{array}$ & $\mathrm{~T}_{2}$ & $\mathrm{~T}_{3}$ & Mean & $\begin{array}{c}2015-1 \\
\mathrm{~T}_{1}\end{array}$ & $\mathrm{~T}_{2}$ & $\mathrm{~T}_{3}$ & Mean \\
\hline Chandler & 166.00 & 155.00 & 140.00 & 154.00 & 160.00 & 153.00 & 142.00 & 152.00 \\
\hline Tioga & 185.00 & 173.00 & 166.00 & 175.00 & 190.00 & 179.00 & 170.00 & 180.00 \\
\hline Fern & 178.00 & 160.00 & 159.00 & 165.67 & 175.00 & 158.00 & 157.00 & 164.40 \\
\hline Selva & 183.00 & 170.00 & 158.00 & 170.00 & 184.00 & 172.00 & 160.00 & 172.00 \\
\hline Blackmore & 173.00 & 160.00 & 152.00 & 162.00 & 170.00 & 157.00 & 149.00 & 159.00 \\
\hline Mean & 177.00 & 164.00 & 155.00 & & 176.00 & 164.00 & 156.00 & \\
\hline \multicolumn{9}{|c|}{$\operatorname{LSD}(\mathrm{P}=0.05)$} \\
\hline Time & \multicolumn{4}{|c|}{10.2} & \multicolumn{4}{|c|}{9.56} \\
\hline Cvs. & \multicolumn{4}{|c|}{12.4} & \multicolumn{4}{|c|}{10.3} \\
\hline
\end{tabular}

NS

Table 5: Effect of planting time and cultivars on number of runners plant ${ }^{-1}$ of strawberry

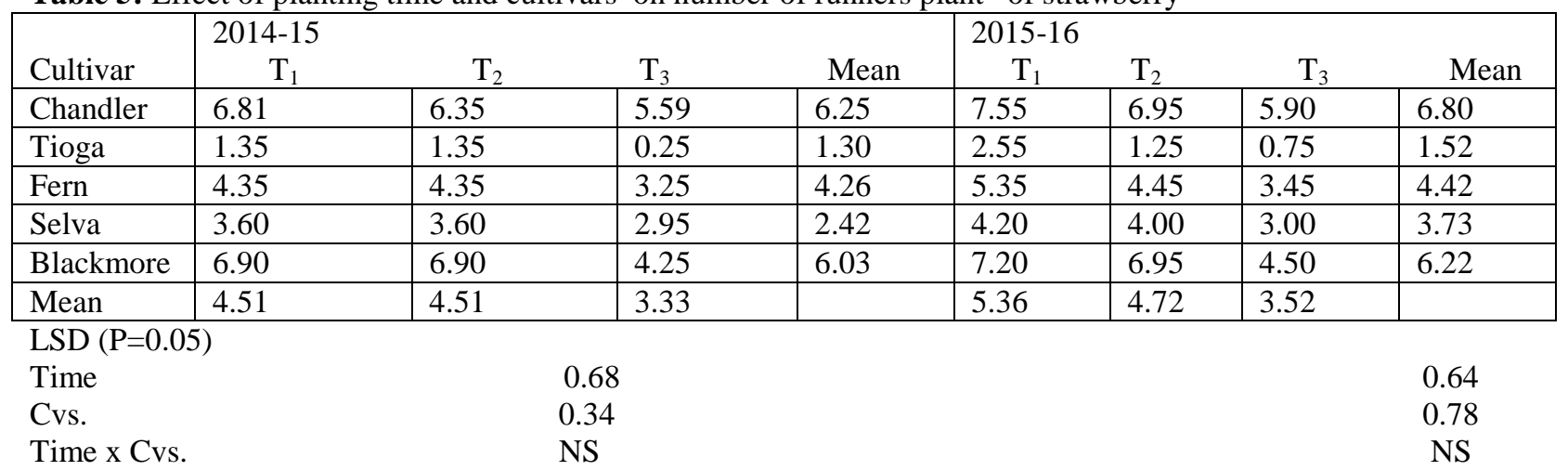

Table 6: Effect of planting time and cultivars on days taken for flower initiation of strawberry

\begin{tabular}{|c|c|c|c|c|c|c|c|c|}
\hline Cultivar & $\begin{array}{c}2014-15 \\
\mathrm{~T}_{1}\end{array}$ & $\mathrm{~T}_{2}$ & $\mathrm{~T}_{3}$ & Mean & $\begin{array}{c}2015-1 \\
\mathrm{~T}_{1}\end{array}$ & $\mathrm{~T}_{2}$ & $\mathrm{~T}_{3}$ & Mean \\
\hline Chandler & 123.64 & 121.91 & 119.81 & 121.79 & 122.95 & 122.16 & 120.95 & 122.02 \\
\hline Tioga & 120.91 & 122.22 & 121.53 & 121.55 & 121.17 & 122.63 & 120.42 & 121.41 \\
\hline Fern & 121.24 & 120.10 & 120.25 & 120.53 & 121.58 & 120.25 & 120.21 & 120.68 \\
\hline Selva & 125.76 & 125.21 & 124.97 & 125.31 & 126.17 & 125.76 & 124.89 & 125.61 \\
\hline Blackmore & 121.52 & 121.24 & 121.22 & 121.34 & 122.32 & 121.94 & 122.19 & 122.15 \\
\hline Mean & 122.61 & 122.14 & 121.54 & & 122.83 & 122.55 & 121.73 & \\
\hline
\end{tabular}

Table 7: Effect of planting time and cultivars on duration of flowering (days) of strawberry

\begin{tabular}{|c|c|c|c|c|c|c|c|c|}
\hline Cultivar & $\begin{array}{c}2014-15 \\
\mathrm{~T}_{1}\end{array}$ & $\mathrm{~T}_{2}$ & $\mathrm{~T}_{3}$ & Mean & $\begin{array}{c}2015-10 \\
\mathrm{~T}_{1}\end{array}$ & $\mathrm{~T}_{2}$ & $\mathrm{~T}_{3}$ & Mean \\
\hline Chandler & 113.11 & 87.49 & 80.04 & 93.55 & 109.61 & 91.11 & 80.00 & 93.57 \\
\hline Tioga & 113.12 & 95.66 & 73.00 & 93.93 & 114.35 & 103.22 & 83.23 & 100.26 \\
\hline Fern & 120.23 & 105.21 & 84.44 & 103.29 & 114.09 & 101.05 & 92.38 & 102.51 \\
\hline Selva & 134.42 & 101.28 & 81.56 & 105.75 & 114.33 & 101.06 & 96.05 & 103.81 \\
\hline Blackmore & 113.56 & 96.16 & 91.89 & 100.54 & 126.67 & 96.10 & 84.46 & 102.41 \\
\hline Mean & 118.88 & 97.16 & 82.19 & & 115.81 & 98.51 & 87.22 & \\
\hline \multicolumn{9}{|c|}{$\operatorname{LSD}(\mathrm{P}=0.05)$} \\
\hline \multicolumn{3}{|l|}{ Time } & 8.20 & & & & & 7.71 \\
\hline \multicolumn{3}{|l|}{ Cvs. } & 11.2 & & & & & 7.95 \\
\hline \multicolumn{3}{|l|}{ Time x Cvs } & NS & & & & & \\
\hline
\end{tabular}


Table 8: Effect of planting time and cultivars on number of flowers plant ${ }^{-1}$ of strawberry

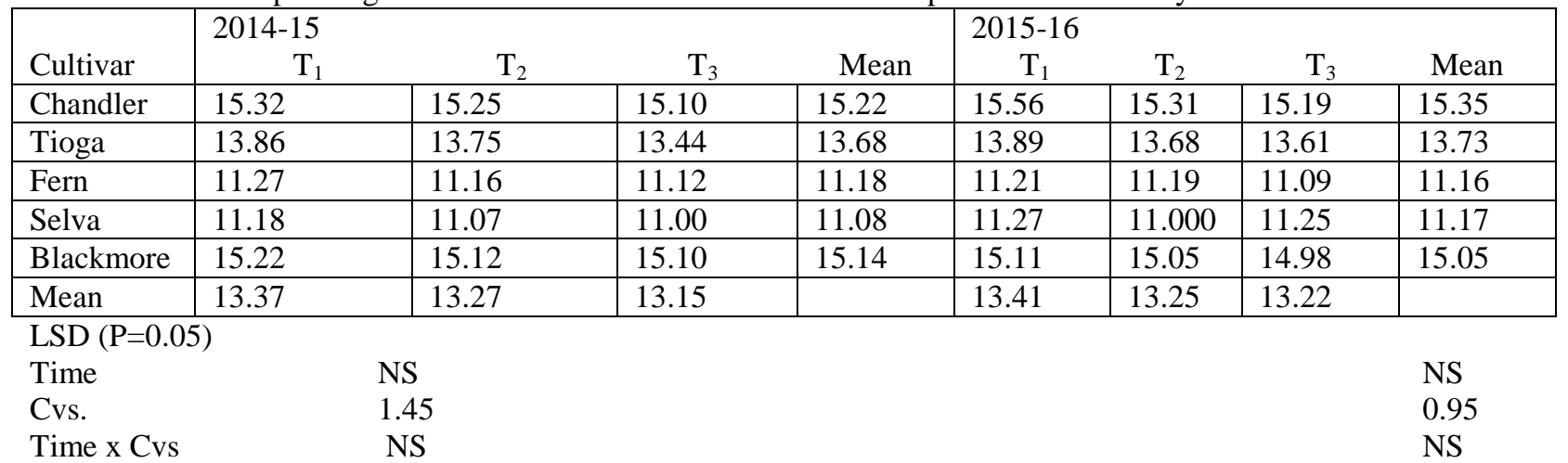

Table 9: Effect of planting time and cultivars on number of fruit set of strawberry

\begin{tabular}{|c|c|c|c|c|c|c|c|c|}
\hline & 2014-1 & & & & $2015-1$ & & & \\
\hline Cultivar & $\mathrm{T}_{1}$ & $\mathrm{~T}_{2}$ & $\mathrm{~T}_{3}$ & Mean & $\mathrm{T}_{1}$ & $\mathrm{~T}_{2}$ & $\mathrm{~T}_{3}$ & Mean \\
\hline Chandler & 13.89 & 13.23 & 13.12 & 13.41 & 13.92 & 13.34 & 13.15 & 13.47 \\
\hline Tioga & 10.56 & 10.22 & 10.16 & 10.31 & 10.58 & 10.25 & 10.22 & 10.35 \\
\hline Fern & 9.67 & 9.22 & 9.11 & 9.33 & 9.56 & 9.28 & 9.10 & 9.31 \\
\hline Selva & 9.02 & 8.95 & 8.23 & 8.73 & 9.12 & 8.82 & 8.28 & 8.74 \\
\hline Blackmore & 12.93 & 12.34 & 12.01 & 12.43 & 12.72 & 12.45 & 12.04 & 12.40 \\
\hline Mean & 11.21 & 10.79 & 10.53 & & 11.18 & 10.83 & 10.56 & \\
\hline \multicolumn{9}{|c|}{ LSD $(\mathrm{P}=0.05)$} \\
\hline \multirow{3}{*}{$\begin{array}{l}\text { Time } \\
\text { Cvs. }\end{array}$} & \multicolumn{7}{|c|}{ NS } & NS \\
\hline & \multicolumn{7}{|c|}{0.87} & 1.05 \\
\hline & \multicolumn{7}{|c|}{ NS } & NS \\
\hline \multicolumn{3}{|l|}{ Time } & & & & & & Cvs. \\
\hline
\end{tabular}

Table 10: Effect of planting time and cultivars on fruit yield plant ${ }^{-1}(\mathrm{~g})$ of strawberry

\begin{tabular}{|l|l|l|l|l|l|l|l|l|}
\hline Cultivar & \multicolumn{1}{|c|}{$\begin{array}{l}2014-15 \\
\mathrm{~T}_{1}\end{array}$} & \multicolumn{1}{c}{$\mathrm{T}_{2}$} & \multicolumn{1}{c|}{$\mathrm{T}_{3}$} & \multicolumn{1}{c|}{ Mean } & $\mathrm{T}_{1}$ & $\mathrm{~T}_{2}$ & \multicolumn{1}{c|}{$\mathrm{T}_{3}$} & \multicolumn{1}{c|}{ Mean } \\
\hline Chandler & 141.19 & 140.52 & 129.73 & 137.15 & 143.35 & 137.92 & 123.56 & 134.94 \\
\hline Tioga & 120.47 & 116.31 & 90.76 & 109.18 & 118.54 & 114.23 & 86.00 & 106.25 \\
\hline Fern & 109.26 & 90.70 & 60.78 & 86.91 & 112.63 & 85.97 & 58.35 & 85.65 \\
\hline Selva & 77.74 & 50.54 & 39.44 & 55.91 & 84.32 & 53.34 & 43.00 & 60.22 \\
\hline Blackmore & 129.89 & 123.52 & 96.00 & 116.47 & 131.10 & 125.32 & 94.34 & 117.00 \\
\hline Mean & 115.71 & 104.32 & 83.34 & & 117.98 & 103.35 & 81.05 & \\
\hline
\end{tabular}

$\operatorname{LSD}(\mathrm{P}=0.05)$

$\begin{array}{lll}\text { Time } & 11.7 & 15.1 \\ \text { Cvs. } & 15.2 & 15.7 \\ \text { Time x Cvs. } & \text { NS } & \text { NS }\end{array}$

Table 11: Effect of planting time and cultivars on marketable yield plant ${ }^{-1}(\mathrm{~g})$ of strawberry

\begin{tabular}{|c|c|c|c|c|c|c|c|c|}
\hline Cultivar & $\begin{array}{c}2014-15 \\
\mathrm{~T}_{1}\end{array}$ & $\mathrm{~T}_{2}$ & $\mathrm{~T}_{3}$ & Mean & $\begin{array}{c}2015-16 \\
\mathrm{~T}_{1}\end{array}$ & $\mathrm{~T}_{2}$ & $\mathrm{~T}_{3}$ & Mean \\
\hline Chandler & 140.00 & 138.21 & 128.93 & 135.71 & 141.47 & 136.93 & 121.54 & 133.31 \\
\hline Tioga & 119.45 & 114.11 & 85.22 & 106.26 & 118.08 & 114.00 & 87.96 & 106.68 \\
\hline Fern & 108.36 & 85.82 & 56.21 & 83.46 & 113.59 & 85.21 & 57.97 & 85.59 \\
\hline Selva & 75.98 & 53.00 & 42.95 & 57.31 & 83.16 & 53.22 & 41.18 & 59.19 \\
\hline Blackmore & 126.24 & 124.76 & 92.97 & 114.65 & 130.34 & 124.13 & 94.94 & 116.47 \\
\hline Mean & 114.00 & 103.18 & 81.26 & & 117.33 & 102.69 & 80.72 & \\
\hline
\end{tabular}

$\operatorname{LSD}(\mathrm{P}=0.05)$

Time

12.4

12.1 
$\begin{array}{lll}\text { Cvs. } & 16.0 & 15.7\end{array}$

Time $\mathrm{x}$ Cvs. NS NS

\section{References:-}

1. Ahsan, M.K. , Mehraj,H .,Hussain, M.S.,Rahmann, M.M. and UddinA.F.M (2014).Stusy on growth and yield of three promising strawberry cultivars in Bangladesh. International Journal of Business, Social and Scientific Research 1(3):205-208.

2. Bakshi P, Bhat DJ, Wali VK, Sharma A and Iqbal M(2014). Growth, yield and quality of strawberry (Fragaria $\mathrm{x}$ ananassaDuch.) cv. Chandler as influenced by various mulching materials. African Journal of Agricultural research.9: 701-706.

3. Asrey,R. and Singh, R. (2004). Evaluation of strawberry varieties under semi-arid irrigation region of Punjab. Indian Journal of Horticulture,61:122-124.

4. Athwal, B.S. (1976). Studies on the performance of some strawberry varieties in the plains of Punjab. MSc. Thesis. GNDU Amritsar.

5. Bedard, P.R., Hsu, C.S., Spangelo, L.P.S., Fejer, S.O. and Rousselle, G.L. (1971). Genetic, phenotypic and environmental correlation among 28 fruit and plant characters in cultivated strawberry. Canada Journal of Genetics Cytol 13: 470-479.

6. Beniwal, L.S., Daulta, B.S. and Bisla, S.S. (1989). Evaluation of different strawberry cultivars under Hisar conditions I- Growth, Flowering and Fruiting. Haryana Journal of. Horticulture Science 18: 34-39.

7. Biswas,M.K.K., Dutt, U.K. Roy,R. Islam and M. Hossain (2009). Development and evaluation of in vitro somaclonal variation in strawberry for improved horticultural traits. Scientia Horticulturae,122:409-416.

8. Darrow, G.M. (1966). The strawberry. New York: Holt, Rinehart and Winston.

9. Dhaliwal, G.S. and Singh, K. (1983). Evaluation of strawberry cultivars under Ludhiana conditions. Haryana Journal of Horticulture Sciences. 12 : 36-40.

10. Dhillon, A.S. (2005). Effect of bio-regulators on growth and cropping in strawberry under sub-tropical conditions of Punjab. M.Sc. Thesis, Guru Nanak Dev University, Amritsar India.

11. Dhiman, K. (2003). Studies on Genetic variability and selection in strawberry (Fragaria X ananassa Duch) for yield and quality traits. Dr. Yashwant Singh Parmar University of Horticulture and Forestry. Nauni, Solan (H.P.) India

12. Hancock, J.F. and Bringhurst, R.S. (1983). Yield component interactions in wild populations of California Fragaria. Horticulture Science 23 : 889-890.

13. Karakara, B.K. and Dwivedi, M.P.2002. Strawberry. In: Enhancement of Temperate Fruit Production in changing Climate, K.K. Jindal and D.R. Gautam (eds.).UHF,Solan.pp.198-204.

14. Kidmos, Y., Anderson, H. and Peterse, O.V. (1996). Yield and quality attributes of strawberry cultivars in Denmark. Fruit Variety journal. 50 (3): 160-167.

15. Lal, S.D. and Seth, J.N. (1980). Correlation studies in strawberry (Fragaria x ananassa Duch.). Indian Journal of Horticulture. 37: 371-375.

16. Rieger, M. (2006). Introduction to fruit crops. Food product press. An Imprint of the Haworth Press Inc. New York.

17. Sharma, R.L. and Badiyala, S.D. (1980). A study on the performance of some strawberry (Fragaria $\mathrm{x}$ ananassa) cultivars in the mid hill region of North India. Prog.Hort 12 (2):17-23.

18. Sharma, R.M. and Yamdagni, R. (2000). Modern strawberry cultivation. Ludhiana, India, Kalyani Pub 37 (1) :163-165.

19. Singh, G.P. (1982). Investigation on vegetative growth, flowering and fruiting in strawberry under sub-tropical conditions. MSc Thesis. Punjab Agriculture University, Ludhiana.

20. Singh, H. and Singh, R.(1979). Effect of gibberellic acid and manuring on the growth, flowering and yield of strawberry.Indian J.Hort 35:207-11.

21. Tanaka, Y. and Mizuta, M. (1974). Nutritional - physiological studies on strawberry cv. Hokowase in long term cultivation. I. Influence of nitrogen on growth, yield and absorption of nutrients. Bul. Nara Agri. Expt. Sta 6 :38-43. 